\title{
The Private and Public Lives of the Hmong Qeej and Miao Lusheng
}

\section{Catherine Falk}

he Hmong qeej, sometimes called the lusheng ${ }^{1}$ when used by
the Miao in China, is a musical instrument which presents divergent and multiple personalities in its history, musical styles and contextual applications. On the one hand, the sound of this set of free reed pipes signifies death; on the other, it is used as a tool of public and happy display. In this chapter, I propose that the qeej occupies at least two spaces in Hmong thinking about themselves. The first space is for Hmong ears and eyes only. It occurs during funerals inside the house, the place of clan-specific behaviour and ancestral jurisdiction. It is private, proscribed, for Hmong audiences and communal Hmong benefit. The second space is overtly public and outdoors. There, performance practice norms are deregulated, and are intended as much for personal benefit as for communal well-being. At New Year and other renewal festivals, the qeej is presented as an icon of Hmongness for both Hmong and nonHmong audiences.

An examination of the private and public lives of the qeej provides a refractory lens for viewing Hmong/Miao constructions of their identity, as well as their responses to changing 
circumstances. The manipulation of the qeej both by the Hmong and by the dominant societies with which they coexist exemplifies numerous ways in which the Hmong present their perceptions of themselves as a minority and marginalised group both to themselves and to others. These include firstly, the deeply held understanding that lost knowledge was regained and incorporated in the received texts communicated by the qeej, and that the essential meaning of knowledge regained is best preserved by being concealed and embedded within frames or layers of deceptive and outward 'noise'; and secondly, that ownership of knowledge and meaning can be controlled either as esoteric and internalised, or as exoteric and externalised assertions of identity (Cohen 1989: 69, Peterson 1988: 13).

Running parallel to these understandings are the theories that the body of meaningful knowledge about being Hmong becomes increasingly impoverished the further the population is removed from China; and that 'shared cultural space no longer depends upon shared geographic place' (Lipsitz 1994: 6). None of these ideas about Hmong 'self-conscious recognition of collective identity' (Peterson 1988: 13) is new, but when they are applied to the qeej's performance contexts and musical structures, they furnish us with some interpretative clues about the contradictory nature of the instrument as a harbinger both of grief and love, as a vehicle both of intensely personal and symbolically communal communications, as an apparatus which both preserves the most serious archive of Hmong cosmology and presents a public face in which musical presence and meaning is primarily emblematic, and about the reasons why one of the most important Hmong texts is disguised so deeply that almost no one can understand it (Falk 2003b, 2004a, 2004b).

In this chapter I attempt to reconstruct the private and public lives of the qeej through time and place, in China from the Zhou dynasty (about 1100-771 BC) to the present, and in the diaspora to Thailand and Laos and thence to Western countries, from the late eighteenth century to the present. The sources I have examined include accounts of Miao life by Han tourists in the eighteenth and nineteenth centuries, by Western missionaries, 
sojourners and ethnographers from the mid-nineteenth century, and by the Hmong themselves on the World Wide Web in the late twentieth century. ${ }^{2}$ A cursory (and as yet undeveloped) glance at the qeejs appearance as an accessory in Hmong stories ${ }^{3}$ and textile arts adds a further ingredient to the tale of the qeej, and awaits a coherent interpretation. I will also demonstrate, briefly, how the musical structures used by qeej players differentiate its private and public musical repertoires. First, I will describe the many personalities of the instrument.

\section{Qeej Roles}

The qeej fulfils many roles in Hmong life, which I have broadly categorised as 'private' and 'public'. By 'private' I mean the restricted appearance of the qeej for a Hmong-specific audience, predominantly during funerals, where it is in turn a pedagogue, a speech surrogate, an entertainer and a psychopomp. At funerals, using qeej language, it instructs the soul of the deceased about death and the journey to the ancestral world. In between its didactic duties, it entertains both the living participants and an invisible audience made up of the deceased, the spirits and the ancestors, all of whom are said to enjoy its music very much. Along with the souls of sacrificed roosters, it announces the arrival of the soul of the deceased at the doors of the kingdom of the Lord of the Other World, Ntxwj Nyoog, and at the realm of the ancestors. In its public manifestations, the qeej appears outdoors both for Hmong and non-Hmong audiences, where it is employed variously, as a 'girl-catcher' (a term used by Catlin 1997a: 79), as an emblem of pan-Hmongness, as a marketable and commodifed symbol of ethnic exoticism, and as an instrument of cultural revival and education among Hmong in the West.

I suggest that the qeej is used in its public role as a decoy, a 'double agent', diverting the gaze of others from its fundamentally secret life in funeral ritual. In a more political interpretation, the dichotomous representations of Miao by the Han as 'raw' (sheng) and 'cooked' $(s h u)$ can be applied to qeej roles. In its private role the qeej approximates the Han designation of sheng Miao, 'raw', or 
an unassimilated, rebellious and primitive people, while the public life of the qeej in contemporary China and the West embodies the virtues of shu Miao - 'cooked,' assimilated citizens of the dominant society.

\section{Aspects of the Qeej Common to Both Roles}

Some aspects of the qeej transcend the private/public dichotomy. Firstly, the instrument is played only by men, and I have suggested elsewhere that there are epistemological, as well as purely physical reasons for this (Falk 2003a). Secondly, organologically the Hmong qeej and Miao lusheng are differentiated from other multiple free-reed type instruments in China and Southeast Asia, such as the Han sheng, the Lao khaen, the Dong (Kam) lusheng and the Lisu folu' 'o' ô $0,{ }^{4}$ by their construction and by their position relative to the player's body. The Hmong qeej has a wooden, rather than a gourd, wind chest, ${ }^{5}$ and its pipes run at right angles and horizontally, rather than parallel and perpendicularly, to the player's body.

Next, the qeej is a dancer, and its associations with dance date very far into the past. The movements of the dance differ in their form and intent according to the occasion. During funerals, the qeejs prescribed and relatively sedate circling around the funeral drum transports the soul of the deceased and the message of the qeej from the world of the living to the spiritual world (Mareschal 1976: 261). However, at festivals and other outdoor occasions, particularly at times when young men and women get together, young qeej-playing men turn somersaults and otherwise perform spectacular feats of virtuosic acrobatics. ${ }^{6}$

The distinction between serious ritual movement and showy public dance while playing the qeej was confirmed by the testimony of two respected and well known qeej players in California, Nhia P. Xiong and Bla Seng Xiong. ${ }^{7}$ They say that at funerals certain movements by the qeej player are required at certain times, including kneeling (ntaus caug) and walking under the hanging drum (chaws qab nruas), and these movements have special meanings. They must be performed correctly out of respect 
for the deceased and his or her family. On the other hand, they say, young players nowadays 'can put on a good show' (dhia qeej), but cannot really 'blow qeej (tshuab qeej) - make sense other than making some sound. A true tub dhia qeej is one who can dance and still be able to play the words of the song correctly, and a real qeej master can tell the difference. However, this 'showing off' is also the proper way of presenting one's talents to the public (Nao Xiong, email, 18 February 2003).

The concept of the inseparability of choreographed movement and playing the qeej seems to be embedded linguistically. The expression dhia tshov qeej, 'to dance blowing the pipes' is discussed by Jarkey as a special case of 'co-temporal' serial verb construction in Hmong. In this type of construction, two actions are described by two verbs juxtaposed within the same clause, and can be thought of as constituting two facets of a single event:

Observe the following example:

Nws dhia tshov qeej.

3SG dance blow bamboo pipes.

'He dances (while) playing the pipes.'

Although these might seem like two distinct actions, in fact, to a Hmong person, they are inseparable: whenever the qeej is played, the performer's feet and body move and sway. Playing and dancing are not two events, but one. This assertion is supported by the fact that the verb dhia 'dance' can be used alone to describe the same situation:

Nws dhia qeej.

3SG dance bamboo pipes.

'He dances the pipes.' (Jarkey 1991: 169-70). ${ }^{8}$

References to the qeej in the travellers' and missionaries' writings frequently mention its role as a dancer (see, for example, Abadie 1924: 162, Agnew 1939: 17, Bridgman 1859: 286, Graham 1937: 31, Hosie 1897: 231, and Schotter 1909: 344). Lunet de la Lajonquière comments:

Ils [Les "Meo"] dansent ... dans certaines cérémonies, les funérailles par example: le danseur ou les danseurs jouant du sen [qeej], le corps légérement penché en avant, tournent tantôt à droit, tantôt à gauche, sur un pied, puis 
sur deux, sautent sur place, avancent ou reculent sans que le haut du corps quitte sa position première et que le chant de l'instrument soit arrêté (1906: 312).

A character in one of Graham's Ch'uan Miao stories tells how

When we study the lusheng we will secure good tunes. One who studies a tune should study a good way of dancing (1954: 102).

Fourthly, the qeej is most probably of great antiquity. We know from myth, iconographic and literary evidence that the multiple-piped free reed instrument type has existed in China for thousands of years. ${ }^{9}$ Although there is no proof of the longevity of the instrument's use by the Hmong/Miao, Hmong stories about the origin of the qeej attest to its function as a repository of knowledge and its power to unite the voices of disparate people (Falk 2003a), and place the invention of the instrument at the beginning of Hmong history. In most of these Hmong origin tales, the first qeej was made by men on the initiative of a divine source. The Great Deity, Saub, or his support in some spiritual matters, the Dragon, showed Hmong people how to conduct wedding and funeral ceremonies using the qeej when knowledge, often in the form of books and writing, was lost during the time of the Great Flood.

Lastly, the qeej is animate, a living organism which speaks and breathes. The names of its parts have anthropomorphic attributions. ${ }^{10}$ Xiong (1999) comments that the wind chest is called 'the lungs' of the instrument. The action of the player's breath and fingers on the 'mouth' (ncauj - mouthpiece), 'lungs' (taub - windchamber) and 'fingers' (ntiv — pipes) brings the instrument to life. Graham noted this: 'The liu sheng is alive, and when played it is regarded as speaking' (1954: 9). ${ }^{11}$

\section{The Private Life of the Qeej: Funerals}

During funerals, the qeej addresses the soul of the deceased with flowery poetic language for at least three days. Men first learn these 
poetic texts of death as 'thought-songs' (Catlin 1997a, after Boilés 1967), which are then converted into qeej language using four of the qeejs seven pitches to encode the eight linguistic tones in a process of speech surrogacy. Yang Lee described the process of encoding linguistic tone as musical pitch most eloquently when he said 'my fingers catch the words on my breath' (personal communication, Melbourne, 3 September 2000). The funeral speech of the qeej is not regarded as 'music': it is a set of instructions, a didactic liturgy (Pao Saykao, personal communication). The text transports the soul from the world of the living to the realm of the ancestors, binding past, present and future generations of Hmong clans. The correct performance of the qeejs texts of death is essential to being Hmong and differentiates Hmong people from all others, as the qeejs text demonstrates. ${ }^{12}$

The qeejs instructions are only understood by the inhabitants of an invisible world - the soul of the deceased, the ancestors, and Ntxwj Nyoog. This audience hears and understands semantically meaningful sounds. To the living, the sound of the qeej is 'noise', although the combination of the sounds of the funeral drum and the qeej announces death. The meaning of the message is deliberately concealed so that living souls do not inadvertently follow the soul of the deceased on the journey of death. The qeejs message is powerful and dangerous. It is disguised not only from the living, to preserve their lives, but also from outsiders or enemies, to preserve the integrity of Hmong identity. The contents of the funeral texts, both sung and played on the qeej, appear to have retained a remarkable stability over time and place (Falk 1996, and Falk forthcoming a). The Hmong funeral remains one of the most powerful affirmations of Hmongness wherever Hmong people are found, including in Western countries (see Falk 1994a, and 1994b). Funerals in the West are truncated facsimiles of those in Asia, for many reasons, but the presence of the qeej is mandatory.

Qeej 'music' at funerals buries and frames semantically meaningful tones in musical noise in both vertical and horizontal structures. The message is deliberately concealed in a complex 'web' (Catlin 1982: 193) of musical polyphony, drones, ambiguous 
communicatory 'noise' (Stern 1976: 129), movement, and poetic language. Semantic meaning is frequently framed within each song by lengthy sections of qeej 'noodling' (ntiv) in which the lower drone is heard, as well as the technique of 'sucking the qeej (nqus qeej) to produce short detached sounds. Xiong refers to these complicated and difficult to learn passages as 'resting cushions', where the player can 'relax his lungs', and notes that they distinguish the beginnings and endings of songs (Xiong 1999: 3). Passages of meaningful pitch are embedded beneath the two upper drones and sometimes within clusters of other pitches. Communicatory 'noise' occurs in the frequent repetition of formulaic phrases, in particular the appellation leej tub tuag, 'beloved dead one', which when translated into qeej sounds is the iconic musical phrase of the entire funeral repertoire. 'Noise' is also inherent in the rules of qeej text delivery which demand, for example, that no two notes of the same pitch can be played consecutively, as this would obscure the semantic meaning of words which have different meaning but the same or similar spoken melodic and pitch contours. The noisy, loud sound of the second highest drone punctuates the delivery of both text and noise. It is produced by inhalation of breath. This blurted and insistent sound commands the dead soul to pay attention to the qeej (Yang Lee, personal communication, Melbourne, 3 September 2000), just as the frequently repeated identifying phrase leej tub tuag insists that the text is intended for the dead, not the living. The inhaled drone is used exclusively in funeral music; when the qeej plays instrumental versions of secular song (kwv txhiaj) the finger hole for this pitch is stopped (Mareschal 1976: 156). The upper drone sounds almost continuously. Music of death is characterised by the combined sounds of mouth organ and drum, semantically burdened pitches, the heraldic use of the upper drone, the repeated musical appellation which calls on the dead, and melodic phrases which are specific to each verse of the qeej's funeral utterances. These characteristics distinguish the qeej's 'death music' from its 'music for fun' (qeej ua si).

Knowledge of the qeej's texts and true mastery of the instrument's funeral repertoire is an indication of great erudition 
and is accorded very great respect. Serious qeej musicians regard the 'showing off' by young players during New Year festivals as 'immature' (Xiong 1999: 2). Playing the qeej at funerals requires not only a prodigious memory, but also great stamina: 'One has mastered the qeej when he can blow flames of fire out of the bamboo pipes and unearth giant poles with the tips of the pipes' (Xiong 1999: 3). Knowledge of the qeejs funeral repertoire does not come cheaply: the cost of lessons is two silver bars or balls, as Yang Lee told me (personal communication, 3 September 2000). ${ }^{13}$

In its private life the qeej thus embodies Hmong knowledge about Hmong identity in a highly respected and valued mode of social and musical competence. This knowledge is too dangerous to bandy about, and too powerful to reveal to outsiders or others.

\section{Early Accounts of the Qeej}

Early accounts of the use of the qeej in Hmong/Miao life in China, and later in Laos and Thailand, privilege its role in public festivals and courtship over its funerary duties. The earliest sources refer to the lusheng's use among a sort of generic barbarian ethnic minority called 'Miao', and we cannot assume that they were Hmong. Later, we can partially track the use of the instrument among the White, Flowery and Black Miao in China, and among the White and Green Hmong in Laos, Thailand and the West. Nineteenth century and pre-World War II accounts of the use of the qeej, which specify ethnic provenance include, for the White Hmong, (or Ch'uan Miao or Pe Miao), Lunet de Lajonquière (1906: 311-12), ${ }^{14}$ Schotter (1909: 344), ${ }^{15}$ Seidenfaden (1923: 171), ${ }^{16}$ Graham (1926: 305, and 1937: 31-2), ${ }^{17}$ Agnew (1939: 13-17), ${ }^{18}$ Lin (1940-41: 284, 330-1), Bourotte (1943: 38, 49 and 51) and Bernatzik (1970). The qeejs presence among the Flowery (Hua) Miao is mentioned by Bridgman (from the Miao albums) (1859: 286), Clarke (1911: 63-6), Hudspeth (1937: 12-13) and Lin (1940-41). Mickey (1947) deals with the lusheng among the Cowrie Shell Miao. ${ }^{19}$ Black (Heh) Miao and their bands of huge lusheng are described by Bridgman (1859: 286), Broumton (1881: 225-6), Hosie (1897: 231), Betts (1899-1900: 101-2), Clarke 
(1904: 203-4 and 1911: 63-6) and Beauclair (1960: 144, 151-2, 170-1). Unspecified 'Miao' who use the lusheng are mentioned by du Halde (1736: 61-67), ${ }^{20}$ Lockhart (1861: 185), Liu (1934: 31-2), Wu (1940: 842), and Eberhard (1970: 223-7).

Reconstructing the history of a musical instrument from an oral tradition based on written accounts by casual observers, whose agendas were far removed from contemporary musical ethnography, is at best serendipitous and at worst haphazard. There are, of course, no sound recordings from the distant or even quite recent past available for analysis or comparison. Nevertheless, some patterns emerge.

\section{Pattern 1: Silence in the Early Literature about the Private Life of the Qeej}

The nineteenth and early twentieth century reports sent home from Miao areas in China by European missionaries and officials are almost completely silent when it comes to observations of music in Miao life, let alone the qeej. ${ }^{21}$ In musical matters, most evangelists were more concerned to teach the Miao to sing Christian hymns than to learn about indigenous music. ${ }^{22}$

The qeejs private role in funerals is mentioned only among the White Hmong, starting with Schotter (1909), and Mickey (1947) for the Cowrie Shell Miao. All the other White Hmong sources listed above only describe the use of the qeej in public activities at festivals and in courtship. These accounts derive from travels in southwest China, with the exception of Seidenfaden, Lunet de Lajonquière and Bernatzik, all of whose encounters with Hmong took place in northern Thailand. Interestingly, these latter writers report that funerals are the only occasion on which the qeej is used: Bernatzik reports that the social use of the qeej is not customary among the Miao in Thailand (1970: 207)23 and Seidenfaden is adamant that the qeej is only used at funerals among the White Meo of Chieng Mai (1923: 171). Detailed analysis of the musical role of the qeej in funerals did not occur until Mareschal (1976) and Schwörer-Kohl $(1981,1982)$ published the results of their extended ethnomusicological fieldwork among Green and White Hmong in Laos and Thailand respectively. 
Even if they were invited, the earlier commentators probably would not have relished attending Miao funerals and spending three days and nights in the presence of a putrefying corpse $^{24}$ and in a constantly loud environment. ${ }^{25}$ Silence or absence of comment about Hmong/Miao funerals and their music in these pre-twentieth century accounts does not mean that the qeej did not have a private life. As Brown pointed out in her (re)construction of seventeenth century Indian musical life, we need to read the ethnographic assumptions behind these travellers' reports, ${ }^{26}$ and 'we have to be very careful not to read the frequency with which a musical subject was mentioned by European travellers as an indicator of its indigenous importance' (2000: 23). ${ }^{27}$ Concepts about 'music', about its place in Western life as an elite art form, and self-consciousness about musical illiteracy or incompetence have contributed to a conspicuous aversion among many early ethnographers to engaging with indigenous musical production.

However, there might be more subtle reasons for this silence. Radano and Bohlman have argued that music possesses a powerful role in the construction of racial imaginaries. The alternative to listening to the music that is so inseparable from the racial imagination, they argue, is silence, but at the same time 'music has the power to undo the historical aporia of silence' (2000: 37). Further, they say, 'music gives voice to those silenced by racism ... silence has also served as a racialist weapon because of the power accrued to it through the failure to listen to the music of powerless and voiceless peoples' (2000: 38). On the other hand, obfuscating noise aligns with silence as a mechanism for hiding meaningful sound. Perhaps the 'noise' in the literature about Hmong festivals, which seemed to become increasingly devoid of meaning for the Hmong and Miao, and the commensurate silence about their funerals, an occasion of the deepest ritual meaning and reinforcement of ethnic identity, was controlled by the Miao themselves.

Koltyk noted the silence in contemporary pa ndau (story cloths), in which certain Hmong activities such as opium production, for example, and funerals, are not usually represented, suggesting that because the embroidered cloths 'make a public 
statement about the Self for the Other, certain themes and subject matter are rarely reflected' (1993: 437). A form of essential Hmong knowledge, the funeral, is absent from, or similarly silent in the literature until serious ethnography of the Hmong emerged in the middle of the twentieth century. Bruner's (1986) discussion of the shift in the narrative structure of ethnographies about Native American cultures before and after World War II suggests that the emergence of a new narrative occurred when 'informants and fieldworkers come to share the same stories'. The Hmong after 1975 certainly had a story they were willing to share with fieldworkers as well as an army of sympathetic 'others', and studies of the Hmong incorporating Hmong voices proliferated after the flight to the West.

But let us return to the seventeenth century.

\section{Pattern 2: The Public Life of the Qeej is Morally Questionable}

The earliest reference I have found to the Miao qeej or lusheng dates from 1664. It occurs in an account of a moonlight courtship dance among an unidentified branch of Miao, provided by Lu Tze Yun in the Pei Shu Hsü Yen. ${ }^{28}$ During the Moon Dance young men 'hold flutes which consists of six tubes, two feet in length. They probably have six different notes ... they blow and sing together' (cited in Lin 1940-41: 330-1). Lunar sports at which the qeej is played are also mentioned for the Flowery Miao in the eighteenth century Miao albums (Bridgman 1859: 260). ${ }^{29}$ Liu mentions that du Halde, in 1736, referred to the use of the qeej for grand fetes and weddings (1934: 27). In particular, its role as a 'girl-catcher' is described many times. The qeej was an important component of a young man's courtship technique: nowadays, young qeej players are likened to rock stars (Catlin 1997b). Lu Tze Yun's description of the Moon Dance laments the morals of the Miao at these lunar sports:

They blow and sing together with hands flying and feet dancing. Through exchanges of glances, motion of limbs and tossing of heads, their spirits are aroused ... To begin with immoral intercourse and after that to hold the marriage ceremony, this is the practice ... Oh! The Miao (cited in Lin 1940-41: 331-2). 
Three hundred years later the missionary Hudspeth echoed this despair in his description of Flowery Miao behaviour on moonlit nights when the qeej, and others, come out to play. The qeej was, he says,

... the musical instrument par excellence ... played by the young men, who are popular and admired according to their ability to blow it ... [its tunes] play a dangerous part in the life of the young people. When on moonlight nights pipers come to the outskirts of a village the music is irresistible to the girls, who go out to the players, and after posture-like dancing and antiphonal singing spend the night in their company ... Human nature can sink very low (1937: 12).

The qeej as a 'girl-catcher' also appears in some of the Hmong stories in Johnson's collection. In one story, eligible young women admire a qeej-playing and dancing toad or orphan in the market place. Their parents say 'Girls, you should look for a husband like him' (1985: 231, 384). In another, the daughter of a toad wants to marry an orphan who played the qeej and danced while he played (1985: 161). The connection between toads, orphans and the qeej awaits further investigation.

The public life of the qeej is nowhere more evident than in the marketing of minority ethnic sound and colour by Chinese tourist agencies. Calendars of events advertise a variety of standardised entertainments including 'lusheng' and 'lusheng dance'. Miao, Dong and other minority villages and festivals are on the itinerary along with trekking, giant panda viewings, and scenic tours. The People's Daily Online (http://english.peopledaily.com.cn/200011/11 Accessed 20 August 2002), for example, advertised a 'Lusheng Festival' for November 2000 at which '1500 lusheng players' would perform; 200,000 tourists were expected. Wu Xiaoping points out that among this anticipated crowd would be Western Hmong 'seeking their origins' (2000). The lusheng shares the bill at ethnic festivals with bronze drum dances, costumed choral groups, lion dances, martial arts exhibitions, bullfights, boat races, archery, horse races, pole-climbing contests and athletic events. 


\section{Pattern 3: The Case of the Black Miao}

The use of the lusheng by the Black (Heh) Miao came under the gaze of the missionaries Broumton in 1881,30 Betts in 1899 and Clarke in 1904 and 1911,31 and Her British Majesty's Consul, Alexander Hosie, whose 1897 account of the Black Miao (whom he calls Phö) is strongly reminiscent of Broumton's. ${ }^{32}$ All four described festivals, but not funerals, providing quite detailed and very similar descriptions $s^{33}$ of massed bands of enormous lusheng. Beauclair (1960) continued this tradition in her report of a visit to the Black Miao of southeast Guizhou in 1947. The Black Miao lusheng orchestras were spectacular. ${ }^{34}$

The Black Miao instrument differs from other forms of the Hmong qeej in its size, in its use in a musically organised ensemble, in the use of amplification devices attached to the end of the pipes, and in its position in relation to the player's body with pipes held vertically. Beauclair asserted that 'nothing like it can be found with any of the other tribes' (1960: 171).

\section{Pattern 4: It Looks Like a Bird, Sounds Like a Bird, Dances like a Bird...}

An association between bird imagery and the qeej instrumental type emerges from some of the earlier writings. Tradition holds that in the distant past the Han mouth organ, the sheng, was made to resemble the phoenix bird in shape and sound (Mingyue 1985: 36). There are iconographic as well as written instances of this correlation between birds and the mouth organ. I cannot offer a cogent interpretation based in Hmong cosmology or epistemology for this phenomenon. The association most likely starts with the images on the tympana of the fourth century BC Dong Son drums, ${ }^{35}$ and continues in references in Hmong stories, representations in contemporary story cloths and written sources. In these sources, we find the instrument sounding like a bird, and its players dressed and dancing like birds.

Men playing mouth organs and wearing feathery headgear appear on the tympanum of the bronze Dong Son drums. 


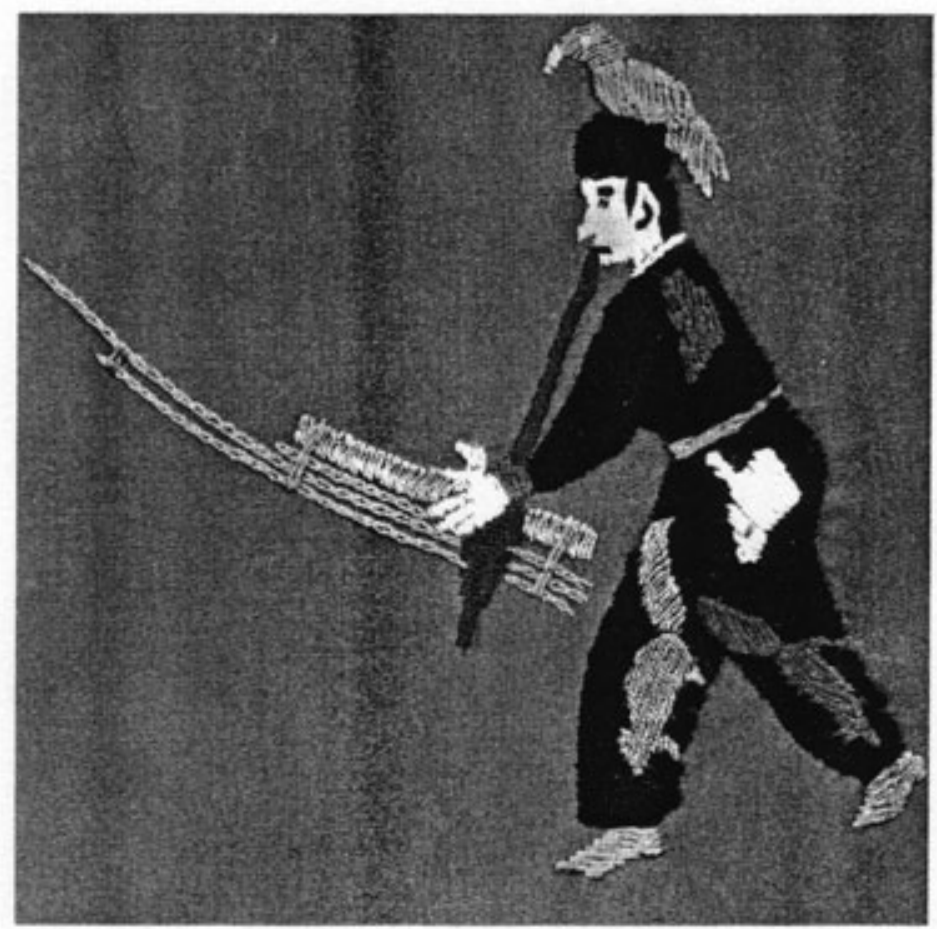

Representation of a mouth organ player with a feather crown on the Hoang Ha bronze drum (from Bernatzik 1970: 654).

Bernatzik described a scene on one drum, allegedly made by the Miao, as follows:

In one of the houses one can see mouth organ players ... Beside each house there are two drums, each resting on a frame ... Between the houses armed men with large feather crowns on their heads are dancing ... A man with a crown, which presumably is made of argus-pheasant feathers, is blowing on a mouth organ (1970: 652-4).

The tympanum he is describing is that of the Hoang Ha drum. Mouth organ players as well as drummers also appear on the Ngoc Lu drum. The instrumentation suggests the Hmong funeral pair, the Lady Qeej and Mr Drum, but these Dong Son 
instruments have upright pipes, parallel to the player's body, not the right-angled pipes of the contemporary Hmong qeej. Catlin assumes that these Dong Son scenes depict the passage to the afterlife (1997a: 78), and Higham also suggests that scenes on the drums possibly show funeral rites, although they could also be fertility ceremonies; he notes further that these scenes are probably representations of aristocratic life, which certainly eliminates the Miao from the discussion (1996: 133). Imagery of birds (as well as toads and frogs) in general is prevalent in the designs of houses and boats on the drums, and in the feathered head-dresses of warriors and musicians. Bernatzik concludes, rather vaguely:

The present absence of the feather crowns among the Meau is thus no proof that the feather crowns depicted on the drum were nevertheless not originally part of the cultural possessions of the Meau ... almost all of the elements represented on the drum are not to be perceived as autochthonous cultural possessions of the Meau. Only the mouth organ could be designated as a Meau element. It, however, is much too widespread among other peoples to appear alone as valid proof [that the Miao made this drum] (Bernatzik 1970: 659-60, my italics).

There is no clear link here to the Hmong/Miao use of the instrument, although Bernatzik reports that a bronze drum from southeast Yunnan was in the possession of 'a Meau chief' (1970: 653). But possession of a bronze drum alone does not point to Miao possession of the mouth organs represented on the drums at the time of their making. However, Miao bronze drum dances are advertised by the Sichuan Provincial Tourism Administration along with 'lusheng and bullfight', as attractions at the 'Miao's New Year' festival in its 2002-2003 calendar of 'traditional ethnic festivals in Guizhou'. According to Liang, the Miao Bronze Drum Dance was described in the Book of Huangping Prefecture and in the Book of Bazhai County of Guizhou; the bronze drum is beaten at festivals and weddings, and at new year festivals men play lusheng and beat bronze drums followed by gracefully dancing women (1987: 93). 
The connection between birds, feathered headgear and the qeej continues to tantalise, however, when the befeathered mouth organ players on the Dong Son drums are compared to the embroidered images of qeej musicians which occasionally appear in contemporary Hmong textiles. In Figures 2 and 3, the position of the feet, the body posture, and the position of the hands are very similar to those of the player on the Dong Son drum in Figure 1. The players in these embroideries each has a small bird (rather than a feathered head-dress) perched on his head. The musicians' dress also shows animal designs, recalling Johnson's Hmong tale which describes a qeej player dressed in animal furs and feathery bird pelts ... all covered with animal tails and birds' wings and claws and beaks and eyes and teeth, furs and feathers' (Johnson, ed., 1985: 346-9).

Liang tells a story of the origin of the qeej in which its sound is likened to the singing of birds: 'the lusheng was made out of tree branches and bamboo to help in the hunt: the sounds it made imitated the singing of birds and the movement of animals' (1987: 82). The same source cites a passage in the Book of Guizhou in which 'some one thousand young Miao men and women dance like birds, playing bamboo lusheng and beating drums for three days and nights' (1987: 80). The Miao albums furnish us with more bird metaphors. Bridgman provides a description of an illustration of the Che Chai Miao ('Aborigines of the Chariot Stockade') in which three men play musical instruments each with a large feather plume in their head dress (1859: 260). At the Moon Dance described by Lu Tze-Yun in 1664, young men 'insert at the top of their hair chicken feathers which flutter gently before the wind. They hold flutes which consist of six tubes, two feet in length. They probably have six different notes' (cited in Lin 1940-41: 330).

\section{Pattern 5: Loss of Meaning and the Impoverishment of Repertoire}

The commentators report a progressive loss of meaning in the occasions on which the qeej appeared in its public life. In 1911, Clarke decided that Miao festivals had come adrift from their original religious purposes (1911: 63-4). Much later, Eberhard 


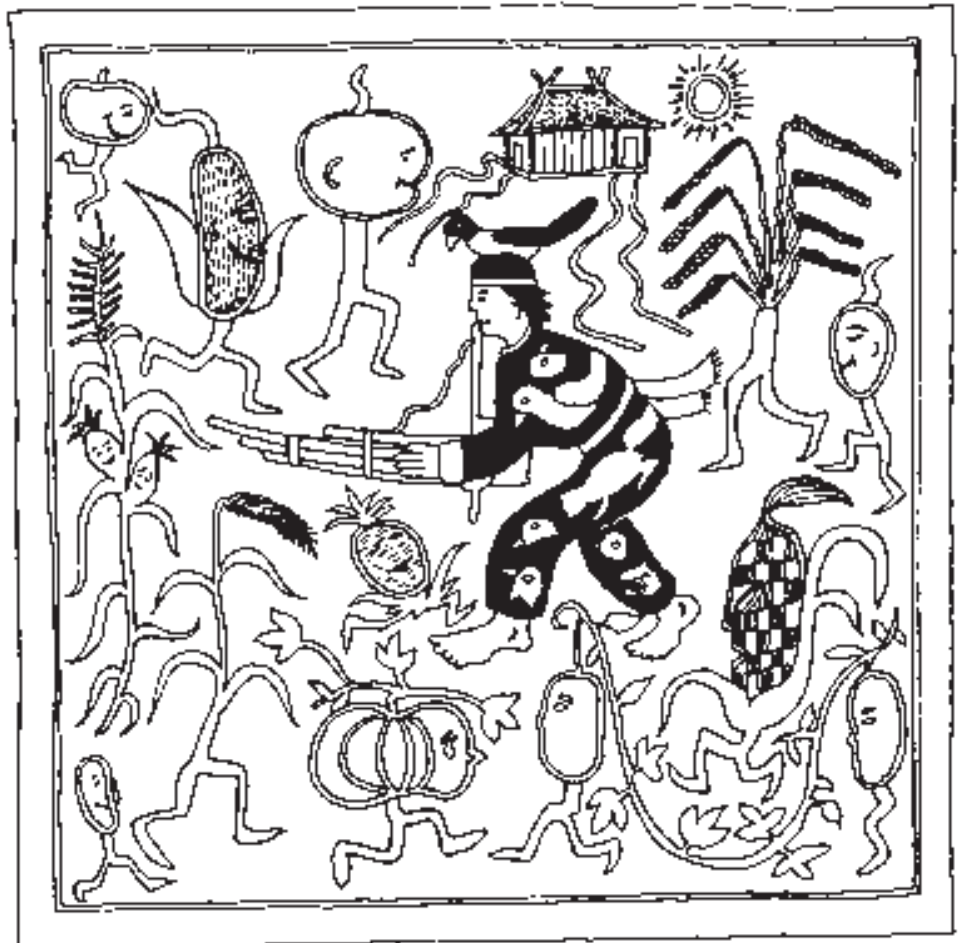

Detail from 'The Flood': 'the orphan is dressed in a coat of animal pelts' (from Bessac 1988, frontispiece. Artist unknown). 


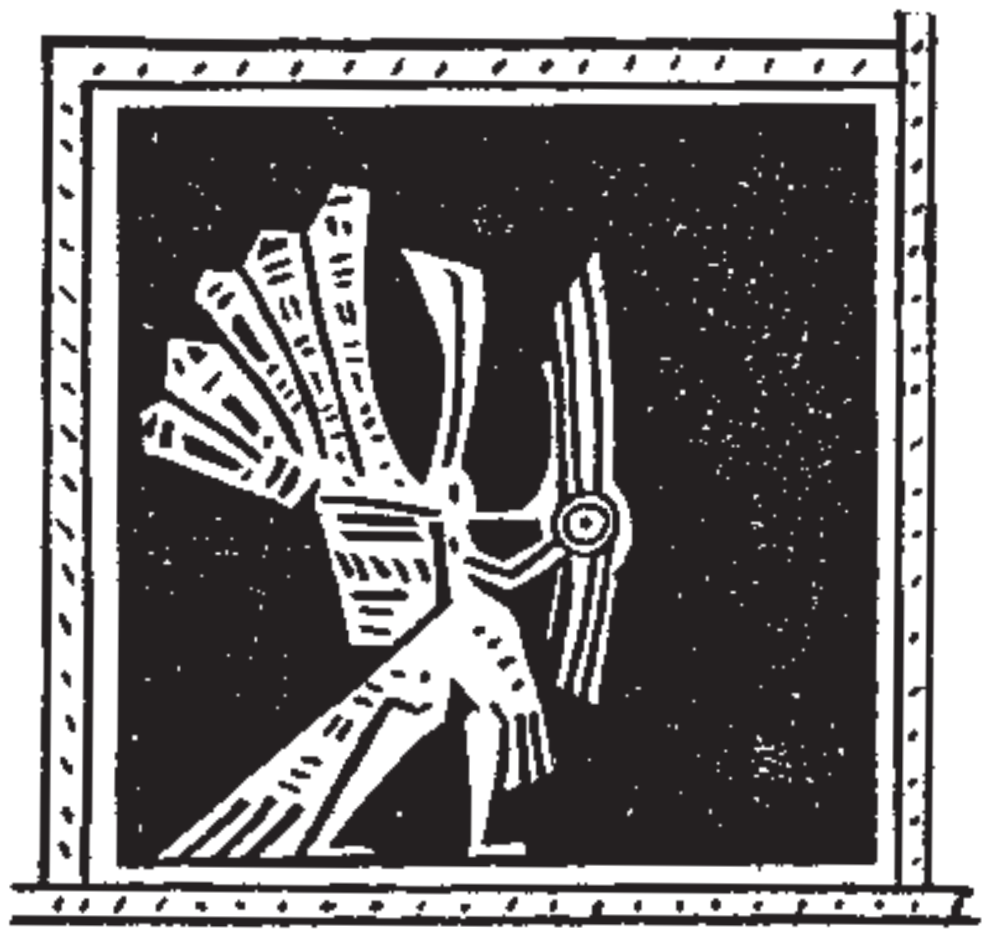

'Orphan boy playing the keng'. Detail from the story 'Why farmers have to work so hard' (from Chan 1990: 14. 'Orphan boy playing the keng'. Artist unknown, cloth from Ban Vinai. Reproduced with kind permission of Anthony Chan). 
reproduced Yü Chu-luan's Reports about the Miaotse of Kueichou (?1931) which noted that 'the real meaning of the festivals, which are undoubtedly a part of agricultural rites, has been almost completely forgotten' (1970: 223). The qeejs use at weddings seems to have been lost long ago. Graham provides a story which tells how the Chinese stole the lusheng from the White Miao during a wedding (1954: 25), ${ }^{36}$ and the wedding repertoire is now lost.

By the late twentieth century, Miao festivals presented for domestic and foreign tourists in contemporary China were almost completely devoid of meaning, according to Diamond:

...the only aspects of traditional religious activity that have survived are the socio-recreational segments of religious festivals ... which have been co-opted by the state as a purely cultural interethnic event under government sponsorship. The songs and dances have been revised to carry politically correct messages, the flirtations and pairings off that used to occur are discouraged. The audience ... is no longer limited to Hua Miao - it has become a cultural diversion for Han Chinese and others (Diamond 1993: 71).

The reification of ritual as performance events for tourists 'made the old people sad and nervous' (Wu 2000). Diamond notes that for the Flowery Miao the state-organised Flower Mountain Festival is a terrible time when crowds of drunken young Han men descend upon their community, trampling fields ... and making insulting remarks to young women' (1995: 112). ${ }^{37}$ The degradation of traditional meaning continues when Miao performance arts are transported out of their rural settings to urban contexts. Liang proudly reported in 1987 that 'in the last three decades or so a number of excellent Miao dance programmes have been choreographed and staged in China. The dances were all developed from the Miao's traditional lusheng and drum dances' (1987: 93). Schein's analysis of state-sponsored and hybridised presentations of minority ethnic customs describes the 'dangerous crossroads', to steal Lipsitz's (1994) epithet, represented by these events at which there is a confluence of misrecognition of signals, firstly by the state as a rejection of feudal superstitions, and 
secondly by the performers as an enactment of nostalgia, all of it clothed in a false aesthetic (or anaesthetic?) of naturalness and authenticity. Schein cites the instance of lusheng players in Xijiang who refused to greet a delegation of Singaporean photographers, not wanting to play at other than conventional times, and provides the following theoretical framework which reinforces my argument that the qeej acts as a 'double agent' in contemporary Miao life:

Codes of protected authenticity were being forged at the intersection of two complementary trends: an appropriative dominant practice that produced valorized tradition to exoticize it, and a proprietary subordinate ethos that recovered and conserved tradition to shield it from the corruption that dominant appropriation entailed (2000: 227-8).

Loss of qeej repertoire runs parallel to loss of ritual meaning. Tapp's 'theory of deteriorating knowledge' (1989: 114, 158) or 'epistemological entropy' (2001: 93) is illustrated by the loss of qeej repertoire. The diversity of vernacular qeej idioms seems to decrease as the population moves away from China. According to Mareschal, qeej genres for competitive jousting competitions and weddings were forgotten during the exodus from China, and an impoverishment of the repertoire of both music and dance is noticeable the further removed the Hmong are from China (1976: 198, 252). The qeejs use as a speech surrogate implies that it spoke in regional vernaculars among Black, Flowery, White and other Hmong linguistic groups in China. The diversity of qeej dialects has probably been lost in migration; at least, the only detailed accounts we possess of qeej language are in Green and White Hmong from Laos, Thailand and Australia (see Falk forthcoming a).

Once the qeej reached the West, its appearance at multicultural festivals or public celebrations of Hmong New Year became almost purely emblematic. It is neither an income-earner for the Hmong nor is it attached to any deep religious meaning. Indeed, Scott described such events as 'mnemonic repositories' in which 'religious beliefs whose daily utility has ended but whose importance in maintaining a sense of ongoing ethnic identity is still very much in evidence' (Scott 1986: 245). The qeej has taken 
on a globalised emblematic function as a symbol of panHmongness which is parallel to the iconicity of the didjeridu for an essentialised indigenous people in Australia, propagated equally by aboriginal and non-aboriginal peoples (see, for example, Neuenfeldt 1997). 'Wherever in the world you are and you see the qeej, you know it's Hmong', says Joe Bee Xiong of Wisconsin on his web page (http://arts.state.wi.us/static/folkdir/xiong3.htm Accessed 12 October 2003).

The qeej is now a tool for cultural revival in the diaspora. At the Hmong Cultural Center in Minnesota, qeej lessons are offered to young Hmong in order to 'bridge the cultural gap between children and their parents, increase children's self-esteem through instrumental lessons and build safe and healthy children' (http://www.hmongcenter.org Accessed 12 October 2003). The convention that restricted qeej playing to men has been broken in the West. Weekly qeej lessons are offered to boys and girls in a Long Beach Hmong Association initiative called 'Qeej not Gangs'. ${ }^{38}$ Nao Xiong (1999), a high school student in the United States, wrote about the qeej on his web-page school assignment in order to 'learn about myself; knowledge of the qeej helped today's generation to learn what it means to be Hmong'. Notation systems for the qeej have emerged. Musical literacy certainly expedites teaching to large groups, although the consequences of musical literacy include a standardisation of oral repertoires, denying clan, linguistic and regional specificity, and the loss of diversity in interpretation and performance practice.

\section{Conclusion}

This chapter has discussed both how the Hmong perceive and represent their most important musical instrument in its public and private lives, and how Others represent the qeej by appropriating the instrument, with Hmong complicity, for particular political and economic agendas. Like its labyrinthine music, the qeej weaves and is woven into a complex web of representations by Hmong for Hmong and others, and by others for others and Hmong. The qeej has trudged every step of the migratory trail with the Hmong, as 
the story of of Chao Yang illustrates: he carried with him eight days worth of rice, an AK47 with 60 rounds of ammunition, and his qeej, sewn into a cloth bag, on his flight across the Mekong from Laos to Thailand; he and the qeej continued on to San Diego (Liu 2002). But in the West the qeej seems to occupy an essentialised position, announcing Hmongness both to Westernised Hmong and to Others through its mere presence as a remembered symbol rather than through its ability to impart deeply meaningful knowledge. The qeej is implicated in competing constructions of knowledge by and about the Hmong as they negotiate their new transnational networks around the world, with travel and telecommunication circuits linking members in real time, in virtual space (see Tapp 2001) and in remembered place. Ownership of the renovated Western qeej appears to belong more to Westernised Hmong than to qeej players who learned their art in Laos or Thailand. The public sounds of the qeej echo back and forth between the diasporic here and now, and a there and then remembered by Western Hmong but lived by mostly disempowered Asian Hmong. The contemporary Western qeej has added to its repertoire of roles, 'selectively preserving and recovering traditions, "customising" and "versioning" them in novel, hybrid and often antagonistic situations' (Clifford 1994: 317).

Examining the changing roles of a musical instrument is one way to test the coherence between sound structures and social structures which Feld suggested so strongly in the conclusion to his first and ground-breaking article about the music of the Kaluli:

For any given society, everything that is socially salient will not necessarily be musically marked. But for all societies, everything that is musically salient will undoubtedly be socially marked (1984: 406).

The qeej has not yet been used in Hmong or Lao rock bands, as far as I know. Its private role as a conduit to the spiritual world has not yet been appropriated by the New Age movement, and its sound has not yet been sampled for exploitation by the transnational world music industry. But change is afoot: Roger Thao, an American Hmong, has devised an electronic amplification system for the qeej so that its individual pipes can be 
heard more readily at public events, creating an instrument reminiscent of the Black Miao lusheng.

In an optimistic version of the future for the qeej, it could be that the adoption of notation systems, the manipulation of the physical object as an artefact of identity-bestowing public display in multicultural environments, and the institution of group music lessons at which young people achieve a passing kinaesthetic familiarity with, but not mastery of the instrument, are examples of the appropriation, disarticulation and re-articulation of the communicative master codes of the dominant culture with Hmong-specific meaning, a process described by Mercer in the context of black independent cinema in Britain (1988: 59). A more pessimistic view would hold that the qeej will lose its private face as the exigencies of Western lifestyles and law cause traditional Hmong funerals to become increasingly difficult to manage, as knowledgeable qeej players die, as the conditions for the one-toone transmission of an oral tradition no longer exist, and as the desire on the part of second and later generations of Western Hmong to receive this knowledge vanishes. The pre-eminence of showy dance in Western public qeej playing focuses the gaze on the individual performer, not the ear on the communal and community-ratifying message enclosed within the arcane and private texts. On the other hand, young American Hmong have learned of the significance of the qeej in Hmong culture by talking to their elders, and hold the instrument in high esteem, as Nao Xiong says:

Knowledge of the qeej and its purposes will allow one to see more clearly what it means to be Hmong ... the qeej plays a very important role in Hmong culture ... It calms when one is frightened; it soothes when one is saddened; it leads the way when one is lost (1999: 3).

It remains to be seen whether the qeej will replicate in diaspora the diversity of its roles and vernacular idioms which it left behind in China, whether it will learn to speak with French, American and Australian accents in its private and public lives, or whether the assimilated, 'cooked' qeej will completely obliterate the quintessentially Hmong 'raw' qeej. 


\section{Footnotes}

${ }^{1}$ Lu sheng means 'six pipes'. Qeej is the Hmong/Miao term; early observers sometimes picked this up in their transliteration. Clarke referred to it as the $k i$ (1904: 203 and 1911: 64) possibly following Broumton's lead (1881: 225), Hudspeth transliterated the pronunciation as ggeh (1937: 12), Bourotte called it the kreng (1943), and Lunet de Lajonquière described a sen (1906: 311).

${ }^{2}$ Websites administered either by or for the Hmong include Hmongonline.com, Hmonguniverse.com, Hmongnet.com, Hmong ABC.com, hmongcenter.org and Click2Asia.com. Young Hmong also post their school assignments about Hmong culture on the web, many involving interviews with Hmong elders in the United States, for example, Ger Lor, Terry Liu, Lao Yang, Pheng Lor, and Nao Xiong.

${ }^{3}$ For example, Graham reports various stories in which a man is able to play several lusheng at once: in one, a man could play nine lusheng at one time (1954: 283); in another, a man could blow three lushengs with every step (1954: 23). Gold and silver lusheng make an appearance in other stories(1954: 235, 252 and 283). In some of the Hmong stories collected by Bessac (1988), Johnson (ed.) (1985) and Tapp (2001) the qeej is associated with orphans and toads.

${ }^{4}$ The pipes of the Lisu mouth organs are positioned away from the player's body, but its wind chest is a calabash (see Larsen 1984: 46-9).

${ }^{5}$ Moule (1908: 94) asserts that wood replaced gourd for the wind chest of the mouth organ during the Three Dynasties (220 AD-280 AD).

${ }^{6}$ Mareschal speculates that a qeej with short curved pipes is more manageable during the dances of the qeej, and this might explain the construction of the Green Hmong qeej (1976: 252).

${ }^{7}$ I am grateful to Nao Xiong who asked his father (Nhia P. Xiong) and cousingrandfather (Bla Seng Xiong) about this matter on my behalf on 16 February 2003 , and communicated the results of his discussion to me by email (18 February 2003).

${ }^{8}$ I thank Nerida Jarkey for pointing this out to me at the one day conference on Hmong research in Australia organised by Nicholas Tapp and Gary Lee during the Annual Conference of the Australian Anthropological Society, Australian National University, 4 October 2002.

${ }^{9}$ Pictographic inscriptions on animal bones and turtle shells excavated in Henan province and dated at least to the eleventh century $\mathrm{BC}$ are believed to depict the sheng (Yang Mu 1993: 21). Doktorski cites a Chinese myth in which the invention of the Han sheng is attributed to a mythical female sovereign in 3000BC (2000: 1). Its use in scenes of seduction as well as at ceremonies honouring the ancestors is documented in the Book of Odes (Shi Jing) (1027-77BC) and a sheng has been excavated from the tomb of the Marquis Yi, dating from 430BC. The Shi Jing (Book of Odes) mentions a 'reed organ' or 'organ' in six of its 311 poems, songs and hymns. The Odes of Wang contextualise the instrument in a love scene, where it is most certainly fulfilling its role as a 'girl-catcher': 
My husband looks full of satisfaction.

In his left hand he holds his reed-organ,

And with his right he calls me to the room.

Oh the joy! (Poem number 67, page 50 of the electronic version, 1998).

Poem number 220, from The Decade of Sang Hu, finds the mouth organ and drum performing 'to please the meritorious ancestors' as part of a seasonal ceremony (page 187). Both public and private roles are reflected in these poems.

${ }^{10}$ The reception of the sounds of the qeej by Europeans ranges from the cultural relativists to the bewildered. In the first camp are the more ethnographically astute commentators: for Schotter the qeej was 'doux et melodieux' (1909: 344); for Graham, 'beautiful music' (1937: 31). Among the latter, the sound of the instrument was 'strange and booming' (Broumton 1881: 225); 'a rude sort of music' (Lockhart 1861: 185); 'not unpleasant to the ear ... but the noise and confusion of sound has a decidedly depressing effect on one's nerves' (Betts 1899/1900: 102); 'very creepy ... and monotonous ... certainly not music, and soon becomes positively exasperating' (Clarke 1911: 64-5); 'weird and monotonous' (Hudspeth 1937: 13), and 'very pleasant to the ear although often a little too monotonous for strangers' (Wu 1940: 842).

${ }^{11}$ Because it speaks, the qeej is fundamentally a solo instrument: its message cannot be heard if many qeej speak at once. Even when several qeej are played simultaneously at funerals, they are not organised musically as an ensemble. I speculate that during the qeej 'jousts' or qeej competitions, which Mareschal reports are now defunct, the qeej engaged in antiphonal dialogue rather than in a musically organised duet. The Hmong aesthetic for the sound of the qeej demands that the individual pipes of one instrument should sound with clarity — phim — when they are assembled, allowing the instrument to speak clearly and sound good (zoo mloog). Each set of pipes is tuned to itself, rather than to a theoretical norm (Mareschal 1976: 172).

${ }^{12}$ For example: You will see that the upper road on your right hand side is full of the hoof prints of horses and cattle. This road is used by other people and Chinese people for doing their business and trading. The road down there on the left- hand side is also full of the tracks of horses and cattle. This road is also used by other people and Chinese traders of fabric and thread. Oh dead one, the road in the middle with clear still water which has no animal footprints is the road for you to take to your grandparents' world. (Verse 11, 'The Song of Expiring Life', recorded on the qeej by Seng Thao, University of Melbourne, 1992).

and from the Qhuab Kev:

... now you will come across three wells, don't drink from the upper well, and don't drink from the lower well, these are for the Yi and the Han, but drink only from the middle well ... if you should hear another cock crowing and your cock does not crow back, that is the path for the Yi and Han people, but if you hear another cock crowing and your cock replies, then that 
is the road of your ancestors ... you will come upon three roads, one to each side, do not take the one to either side, one is for the Yi and one for the Han, but take the road in the middle, with dirty footprints and hoof marks, for that is your ancestors' road, that is the road for you (Tapp 2001: 185).

${ }_{13}^{13}$ Boua Xa Miao declared that 'when you play the qeej for a dead person it means you are giving him money. You know the saliva that comes out of the eyes of the qeej. The dead person's spirit looks at it as coins dropping from the sky' (Boua Xa Moua, in Faderman 1998: 35).

${ }^{14}$ Lunet de Lajonquière notes that the Miao play 'very agreeably' on the sen, a 'sort of organ' made of six or eight bamboo tubes whose sounds are produced by successively inhaling and exhaling (1906: 311-12).

${ }^{15}$ Schotter notes that the 'lou-sen', dancing and drumming occurs at funerals among the Pë Miao or White Hmong of southwest China: 'le son [of the lu sheng] est doux et melodieux ... La rôle du jouer de lou-sen soufflant, sautant, se penchant tout le corps, incliné comme s'il allait s'asseoir, est fatiguant' (1909: 344).

${ }^{16}$ Seidenfaden translated a paper written by Luang Boriphandh Dhuraratsadorn, a District Officer in Chiang Mai, who described the construction of the qeej, and declared that 'music is only used on the occasion of funerals and not at other ceremonies. At funerals the Meo dance and sing' (1923: 171).

${ }^{17}$ Graham notes that 'in the hands of a skillful musician, [the liushêng] is beautiful music. Only men and boys play ... and the player always accompanies the music with dancing' (1937: 31). He lists eight funeral contexts when the instrument is used (1937: 32). In an earlier publication he commented that 'the luh sen is not used at weddings, for its notes are considered too sad for such happy occasions' (1926: 305).

${ }^{18}$ Agnew, perhaps the earliest ethnomusicologist of the Hmong, devoted an entire article to the music of the Ch'uan Miao. He provides a lengthy description of the physical construction of the instrument and its tuning (1939: 15-17) and noted that, as well as its use with the drum at funerals, 'it is also played for amusement only by itinerant Ch'uan Miao lusheng players [who] may be seen in Chinese towns playing and dancing to ever interested audiences' (1939: 17). The full-blown use of the instrument as a source of income from outsiders is heralded here.

${ }^{19}$ Mickey wrote of the Cowrie Shell Miao of Guizhou: 'the lusheng is used by young men to entertain girls who dance at night' (1947: 49). The instrument was also used at bullfights, weddings and funerals (1947: 50).

${ }^{20} \mathrm{Du}$ Halde describes life among the 'Miao tsee' of Sichuan, who are 'more cruel and savage than the Lolos, and greater enemies of the Chinese' and who play on an instrument 'composed of many small pipes inserted into a greater, which has a hole, or a sort of reed, whose sound is sweeter and more agreeable than the Chinese chin ... they know how to keep time in dancing, and express in it, very well, the gay and the grave airs' (1736: 66). 
${ }^{21}$ I have looked at 46 reports from China Inland Missionaries who worked among the Miao, dating from 1895 to 1948 and published in their journal, China's Millions. Not one comments on the use of the lusheng.

${ }^{22}$ For example, Heimbach wrote from his residency at the Shuicheng Miao church in Guizhou:

It was a real treat for me ... to hear them sing such songs as 'I will sing of my redeemer', in good harmony ... [after a baptismal service] the long file of folk wound their way back down the mountain, those baptized were lined up part way down and sang 'Christ the Lord is Risen Today'. It was really lovely and we knew that none but a risen Saviour could have produced such a transformation (Field Bulletin of the China Inland Mission 1948: 9-10).

${ }^{23}$ Bernatzik gives a detailed description of the construction of the instrument and the intervallic relationship between its pipes (1970: 199). He comments that the mouth organ (he does not give it a name) is 'a sacral instrument whose tone is pleasing to the spirits ... [It is also] altogether pleasing even to European ears and resounds over many kilometres in the solitude of the mountains' (1970: 199). It is played only by men, and 'there are real masters but no professionals' (201); 'I never witnessed a dance where the mouth organ was not played' (206). It is used, in a 'cult dance', at funerals and burials (206-7). Bernatzik drew heavily on the writing of Lunet de

Lajonquière (1904), who said that the instrument was used with dance when people were in a good mood, especially on market days when they imbibed heavily, or at New Year festivals conducted in order to please the ancestors; but Bernatzik says he never witnessed this, and concluded: 'Therefore I believe that a dance of the Meau on market days cannot be customary, since ... dancing is connected with the use of the sacral musical instruments which of course are not used on market days' (207).

${ }^{24} \mathrm{Hmong}$ in the United States told Symonds that qeej players 'absorbed much of the pollution as they breathed in the air while they played ... proof of this, they said, was in the bad smell which these men produced when they passed gas' (1991: 252).

${ }^{25}$ Bourotte speculates that the sound of the qeej and drum was so loud that the deceased soul would be happy to depart for quieter pastures:

Le tam-tam bat, le kreng s'exaspère á la limite de sa sonorité comme si on voulait par cette débauche de mélodies saturer le mort de musique et lui faire concevoir les avantages du silence (1943: 54).

${ }^{26}$ See Alison Lewis's description of the encounters between CIM missionaries, Miao, Yi landlords and Han officials for an indication of the context of the reports about Miao life from the Bible Christians (2000).

${ }^{27}$ Alexander Hosie, of Her British Majesty's Consular Service, wrote about his travels in western China and was cogent and perspicacious in his list of reasons for the lack of depth in travellers' accounts of the minority groups. It is worth quoting his impressions of nineteenth century field work at length: Our knowledge of these races [Miao-tzu, Lolo,etc] is defective, for the simple reason that no foreigner has ever paid them a lengthened visit, which is 
essential to a thorough grasp of their ethnological characteristics. Nor is this a matter for surprise, as the opportunities, which foreigners possess of visiting these tribes, whose haunts are removed from beaten tracks, are few and far between; and those few who have had such opportunities have been too much occupied with other work to study ethnological details or acquire a new language ... I passed through the countries of most of these tribes; but, like others, I found myself wanting in leisure to cultivate a closer intimacy with them ... In what does the traveller's day usually consist? He gets up at daybreak, hurries on to the end of the stage, writes up an account of the day's journey, endeavours to get something to eat, and tries to enjoy a few hours' sleep ere the labours of another day begin. The miseries of travel, too, breed a feeling of restlessness and a hankering after something more comfortable ... But all the comfort the traveller in these regions may expect ... is a shelter in a miserable mud hovel without chair or table — hardly a promising spot in which to commence ethnological studies.

Nor is this all ... the next difficulty is to find the man whose characteristics it is intended to study. The treatment which these aborigines receive at the hands of the Chinese, and the contempt in which they are held by them, have induced a timidity which is hard to overcome ... (1897: 225-6).

${ }^{28} \mathrm{Lu}$ Tze Yun's description of the Moon Dance is much cited: see for example, Liu (1934: 32-4), Lin (1940-41: 330-2), and Eberhard (1970: 223).

${ }^{29}$ Bridgman, a missionary, gives translations of 82 sketches of the Miao-tze from one of the Han albums. Among the Che chai Miao, 'Aborigines of the Chariot Stockade', 'men play on instruments and women sing during dancing to the moon, an activity which leads to marriage' (1859: 260). Among the Hua Miao or 'Flowery Aborigines', 'young unmarried men play upon their reed organs' during 'lunar sports' in the first month of spring (276) and among the Heh Miao, 'Black Aborigines', there is a gathering during spring for a 'concert of instrumental music. The largest of [these bamboo] instruments are more than ten feet long and they are played by accomplished masters; others are very short and are used by the secondary players. To these they dance' (286). See Diamond (1995) and Hostetler (1995) for contextualisation and further discussion of the Miao albums, and Oakes for a history of Han colonisation of Miao 'borderlands' (1998: 94-7).

${ }^{30}$ Broumton, a China Inland Missionary, described instruments 18 feet in length, with mouthpieces five feet long and a foot in diameter. 'It requires a great effort to blow them and they produce a strange booming sound, which can be heard at a great distance. When playing ... the musicians moved slowly around the field ... there were five or six of these bands ... each with its circle of dancers' (1881: 225).

${ }^{31}$ Clarke observed thirty or forty groups each of ten instruments at Heh Miao festivals.

${ }^{32}$ Hosie's account is as follows:

The musical instruments are manufactured from bamboos of different sizes, some of them from twelve to fifteen feet long, fitted with a mouthpiece, their 
lower ends being inserted in a large hollow cylinder (the hollowed out trunk of a tree) while the upper end of the longest reed is usually surmounted by a cone made of the sheath which grows at the joints of large bamboos. The instrument is called the $k i$, and from it a loud booming noise is, owing to the presence of a cylinder, extracted. The musicians move round in a circle as they play, followed on the outskirts by the young women (1897: 230-1).

${ }^{33}$ Brown has pointed out that travellers' narratives about India from the seventeenth century observed the convention of repeating observations of remarks made by earlier observers to verify the reliability of their own accounts (2000: 4) and I suspect that this convention applies to the descriptions of Black Miao lusheng bands - Hosie's, for example, is very similar to Broumton's (see endnotes 30 and 32); similarly, Bernatzik repeated much of Lunet de Lajonquière's work.

${ }^{34}$ Listen to Betts on the subject:

... there were thirty-six bands, six instruments to one band, and six sounds to one instrument. These instruments are named luh seng (six musical sounds) and constructed with bamboo pipes having brass reeds, emitting more noise than music. The largest- sized instrument is made of the trunk of a tree hollowed out, a bamboo pipe, 14 feet long ... Thousands of people have arrived from all the countryside ... The bands of six instruments form in line, standing shoulder to shoulder, in the circle formed by the spectators; presently six or seven damsels enter the circle and step in unison with the musicians, in a circular movement ... Heard from a distance the noise of these 36 bands (or 216 instruments), each playing its own tune, is not unpleasant to the ear, but in close proximity, where it is impossible to hear even one's own voice, the noise and confusion of sound has a decidedly depressing effect on one's nerves ... (1899-1900: 101-2).

Moule reproduces Betts' description of the Black Miao lusheng as the substance of his entry on the instrument in his compendious List of the Musical and Other Sound-Producing Instruments of the Chinese (1908).

${ }^{35}$ Some 138 of these drums have been found in Vietnam, Yunnan, Thailand, Cambodia, Malaysia and Indonesia since 1730. Depictions of mouth organ instruments occur frequently in their surface decoration, usually in the context of a row of dancers.

${ }^{36}$ Some considered the sounds of the qeej to be inappropriate: 'its notes are considered too sad for such happy occasions' (Graham 1926: 305). 'Grief and love are incompatible' (Xiong: 1999). Mareschal observed that 'the qeej, instrument of funerals above all, has no place in marriage rites' (1976: 198, translation by the author).

${ }^{37}$ See also Schein's description of Black Miao festivals as a form of 'internalising' and 'externalising' cultural revival in Guizhou (1989).

${ }^{38}$ The California Folk Arts Funding Program granted US \$5000 in 2001 and 2002 to this program. At http://www.folkculture.otg/ctaap_grantees.htm Accessed 15 August 2002. 